\title{
OBSERVATION OF MEDICINES FOR THE TREATMENT OF DIAPER DERMATITIS ON THE PHARMACEUTICAL MARKET OF UKRAINE
}

\author{
(C) O. M. Hlushchenko, T. A. Butkevych, R. M. Khomenko \\ O. Bohomolets National Medical University, Kyiv
}

\begin{abstract}
Summary: diaper dermatitis occurs in every second child of first year of life. Breakdown of the skin barrier function and incorrect care are considered to be the primary cause of dermatitis. The literature data on the causes, symptoms, prevention and treatment of diaper dermatitis are presented in the work. The range of drugs for its treatment, that are available on the pharmaceutical market of Ukraine were studied.
\end{abstract}

Key words: diaper dermatitis, medicines, analysis of the pharmaceutical market.

Introduction. The neonatal period is the most critical age, which is characterized by the features of morphological, functional and biological changes that occur during the child's adaptation to life after birth. There is a high incidence of children in the first year of life on diseases of the skin and subcutaneous tissue. Recently, we can see an increasing proportion of morbidity with atopic dermatitis (10-20\%) [1], contact and diaper dermatitis (25-50\%) [5]. Most cases are associated with genetic penchant, an excessive eating of exotic vegetables and fruits, a high frequency of feeding with artificial mixtures during the first year of life, the widespread irrational usage of antibiotics and other drugs [6].

Despite the wide variety of drugs that have been successfully used in dermatology, the amount of drugs for the diaper dermatitis (DD) treatment is not enough. Medicines for older children or adults that cannot achieve the desired therapeutic effect or even worsens the disease are quite often used. That is why one of the important tasks of modern technology is to increase the range of medicines for DD treatment. State of newborn skin and course of the disease should be considered.

Diaper dermatitis is an inflammatory reaction of the child's skin as a result of the mechanical, physical, chemical and microbial factors influence. Irritant dermatitis of the diaper zone is one of the most frequent types of rashes [10]. It consists of erythema with maceration and may include papules, erosions, and even ulcerations, when severe. The convex surfaces of the buttocks, genitalia, lower abdomen and upper thighs are the places of the greatest affection $[3,10]$.

Diaper dermatitis affects newborns and infants after six months. Y. V. Marushko (2015) and T. A. Bokova et al. (2016) suggest that diaper dermatitis is more often affecting girls, but the studies of American scientists (Ruchir Agrawal et al., 2016) prove that the disease does not depend on gender.
Etiology. Newborn skin is very thin (3-4 layers), the layer between the epidermis and dermis is looser in comparison with skin of older children and adults, thin layer of epidermis is prone to damage, connective tissue is poorly developed, the basal membrane is fragile. That is why the skin is less protected and quickly irritated [1, $3,11]$.

Diaper dermatitis can occur under conditions of:

- late diapers changing - prolonged skin contact with feces and urine;

- mechanical friction - wrong size of diapers or clothing may cause irritation of the skin by constant friction;

- usage of some care products - baby skin can negatively react to wipes, diapers, some kinds of tissues, soap, powders, creams etc.;

- transition from breastfeeding to artificial feeding change of defecation frequency and its $\mathrm{pH}$;

- individual sensitivity of the child's skin;

- usage of antibiotics [8, 10].

Pathogenesis. On the first stage of DD when skin is damaged, the protective function of the horny layer of the epidermis is reduced, skin contact with the feces and urine leads to its excessive moisture, it is easily rubbed and permeability to enzymes, ammonia and urea increases.

The second stage of the disease evolves the inflammatory process, which is manifested by hyperemia, edema, rash (papules, vesicles) in the diaper area. At this stage, as a rule, the accession of microbial infection happens. The formation of redness with exudate and pustules evidences on the accession of bacterial or fungal infection. Most often staphylococcal, streptococcal or candidal diaper dermatitis occurs. The influence of microorganisms causes the most prolonged and severe diaper dermatitis $[1,5]$.

Russian researchers (I. N. Zakharova et al., 2016) developed the clinical classification of the DD severity (Tab.1).

ISSN 2312-0967. Pharmaceutical review. 2016. № 4 
Фармацевтичний менеджмент, маркетинг та логістика Pharmaceutical management, marketing and logistics

Table 1. Clinical rating scale of diaper dermatitis

\begin{tabular}{|c|c|c|c|}
\hline Points & Degree & \multicolumn{2}{|l|}{ Symptoms } \\
\hline 0 & Absent & \multicolumn{2}{|l|}{ Skin is clean, slight dryness and/or a single papule } \\
\hline 0.5 & Easy & \multicolumn{2}{|c|}{ A slight reddening area of less than $2 \%$, single papule and/or light dryness } \\
\hline \multirow[b]{2}{*}{1.0} & \multirow{2}{*}{$\begin{array}{l}\text { Moderately } \\
\text { easy }\end{array}$} & \multicolumn{2}{|l|}{ Mild redness in the area from 2 to $10 \%$} \\
\hline & & Marked redness on the area for at least $2 \%$ & $\begin{array}{l}\text { and/or scattered papules and/or slight } \\
\text { dryness }\end{array}$ \\
\hline \multirow{3}{*}{1.5} & \multirow{3}{*}{ Moderate } & \multicolumn{2}{|l|}{ Mild redness on the area not less than $10 \%$} \\
\hline & & Marked redness in the area from 2 to $10 \%$ & \multirow{2}{*}{$\begin{array}{l}\text { and/or scattered papules, less than } 10 \% \\
\text { of the area and/or moderate dryness }\end{array}$} \\
\hline & & Very intense redness on the area for at least $2 \%$ & \\
\hline \multirow{3}{*}{2.0} & \multirow{3}{*}{ Average } & \multicolumn{2}{|l|}{ Marked redness over the area of 10 to $50 \%$} \\
\hline & & Very intense redness on the area for at least $2 \%$ & $\begin{array}{l}\text { and/or from one to several papules from } \\
10 \text { to } 50 \% \text { with } 5 \text { or fewer acne sores }\end{array}$ \\
\hline & & \multicolumn{2}{|l|}{ Possible slight desquamation or edema } \\
\hline \multirow{3}{*}{2.5} & \multirow{3}{*}{$\begin{array}{l}\text { Moderately } \\
\text { heavy }\end{array}$} & \multicolumn{2}{|l|}{ Marked redness in the area of more than $50 \%$} \\
\hline & & $\begin{array}{l}\text { Very marked redness in the area from } 2 \text { to } 10 \% \\
\text { without edema }\end{array}$ & $\begin{array}{l}\text { and/or the area of more than } 50 \% \text {, with } \\
\text { multiple papules and/or pustules }\end{array}$ \\
\hline & & \multicolumn{2}{|l|}{ Possible slight desquamation or edema } \\
\hline \multirow[t]{2}{*}{3.0} & \multirow{2}{*}{ Heavy } & Very intense redness on the area of more than $10 \%$ & $\begin{array}{l}\text { and/or severe peeling, severe edema, } \\
\text { erosion and ulcers }\end{array}$ \\
\hline & & \multicolumn{2}{|c|}{ Possible large areas of papules, which coalesce or numerous bubbles/acne sores } \\
\hline
\end{tabular}

The main symptoms of diaper dermatitis are blistering, redness, rashes, changes in behavior of the child, such as bad sleep and appetite, feeling of discomfort, trembling, crying, and screaming during diaper changes and washing of the affected areas $[1,8,9]$.

The prevention of DD consists of child's rational care, including timely toilet of the skin, frequent air baths, usage of special wipes that do not contain alcohol and fragrances and are designed not only for gentle cleansing of the skin, but also to moisturize and maintain of the natural $\mathrm{pH}$ balance, usage of care products (cleansers, creams, lotions, etc.) that are adapted for infants, usage of disposable diapers which absorb moisture and their sufficient frequency of change $[3,5,8,12]$.

American researchers (Ruchir Agrawal, MD; Chief Editor: Dirk M Elston, 2016) offered treatment of diaper dermatitis using the ABCDE system (air, barrier, cleansing, diaper, and education):

air - to increase access of air to the affected skin, leaving a baby without diapers for at least 10 minutes three times a day;

barrier - usage of ointments, creams, pastes and lotions which will form a protective film on the baby's skin and treat it at the same time;

cleansing - keep the diaper area as clean and dry, that is possible, change diapers immediately after bowel movements or urination and cleanse the skin;

diaper - choose diapers bigger in size than usual while there is a rash in the affected area;

education - the dissemination of information on proper care of baby's skin, methods of prevention and treatment of diaper dermatitis among parents and guardians $[8,12]$.
Drugs that containe zinc oxide, dexpanthenol (mild diaper dermatitis), nystatin, fluconazole, clotrimazole (upon accession Candida albicans), fusidic acid (upon accession Staphylococcus aureus) are used for the treatment of damaged skin according to the treatment protocol and experts advices. Antihistamine or glucocorticoid medications usage is also recommended in case of severe itching $[8,13]$.

So, the aim of our work was to analyze the range of medicines for the treatment of diaper dermatitis that are presented at the pharmaceutical market of Ukraine.

The object of the study was the informaton of the State register of drugs of Ukraine, formed by "State expert center of the Ministry of health of Ukraine".

Methods of research: search, analysis, generalization and systematization of data.

Results and discussion. According to the ATC classification, the range of medicines for the treatment of diaper dermatitis constitute drugs form several groups: D01 (antifungals for dermatological use), D02 (emollients and protective), D03 (preparations for treatment of wounds and ulcers), D06 (antibiotics and chemotherapeutics for dermatological use) and D07 (corticosteroids, dermatological preparations) [4].

There are 18 drugs, which are used for DD treatment according to the State register of medicines (at 1 December 2016).

Registered medicines belong to the group D dermatological products according the ATC-classification and are divided into 5 subgroups (Tab. 2). Most of them are D03 group drugs (33.3 \%) - preparations for treatment of wounds and ulcers ("Panthecrem", Happyderm-Zdorovie", "Panthenol", "Pantexol Jadran",

ISSN 2312-0967. Фармацевтичний часопис. 2016. № 4 
Фармацевтичний менеджмент, маркетинг та логістика Pharmaceutical management, marketing and logistics

Table 2. Drugs that are used for the pharmacotherapy of diaper dermatitis in Ukraine

\begin{tabular}{|c|c|c|}
\hline The name of the group of medicines & The number of trade names & $\%$ \\
\hline \multicolumn{3}{|c|}{ D01 Antifungals for dermatological use } \\
\hline D01A Antifungals for topical use & 2 & 11.1 \\
\hline \multicolumn{3}{|c|}{ D02 Emollients and protective } \\
\hline D02A emollients and protectives & 3 & 16.7 \\
\hline \multicolumn{3}{|c|}{ D03 Preparations for treatment of wounds and ulcers } \\
\hline D03A Cicatrizants & 6 & 33.3 \\
\hline \multicolumn{3}{|c|}{ D06 Antibiotics and chemotherapeutics for dermatological use } \\
\hline D06A Antibiotics for topical use & 2 & 11.1 \\
\hline \multicolumn{3}{|c|}{ D07 Corticosteroids, dermatological preparations } \\
\hline D07A Corticosteroids, plain & 5 & 27.8 \\
\hline Total & 18 & 100 \\
\hline
\end{tabular}

"Bepanten", "Panthenol-Ratiopharm") and D07 (27.8\%) - corticosteroids, dermatological preparations ("Betlieben", "Hydrocortisone", "Locoid Crelo", "Locoid Lipokrem", "Cutivate").

Among the components of formulation of the studied drugs the greatest proportion belongs to such active pharmaceutical ingredients as dexpanthenol $46.7 \%$, zinc oxide - $20.0 \%$, hydrocortisone - $20.0 \%$, clotrimazole $-6.6 \%$ and fusidic acid $-6.7 \%$.

Analysis of drugs for the DD treatment, depending on the type of dosage form (DF) showed that drugs are represented by the four DF. The greatest number have the soft dosage forms (ointments $-47.4 \%$ and creams $-42.1 \%$ ) (Fig.1).
The assortment of this group of drugs is being shaped by three national and twelve foreign manufacturers (Tab. 3). Among Ukrainian manufacturers the leader is Public JointStock Corporation (PJSC) "Fitofarm" (50 \%), among foreign manufacturers - "Jadran" Galenski Laboratorij d.d., Croatia (14.3\%) and Temmler Italia S.r.l., Italy (14.3\%).

By legal status $42 \%$ of drugs used for the treatment of diaper dermatitis are released from drugstores and their structural units with prescription [2, 4].

Conclusions. There were 18 drugs, which are used for treatment of diaper dermatitis according to the State register of medicines (1 December 2016). $95 \%$ of them are intended for the treatment of both children and adults and more than $20 \%$ of drugs can be used only for

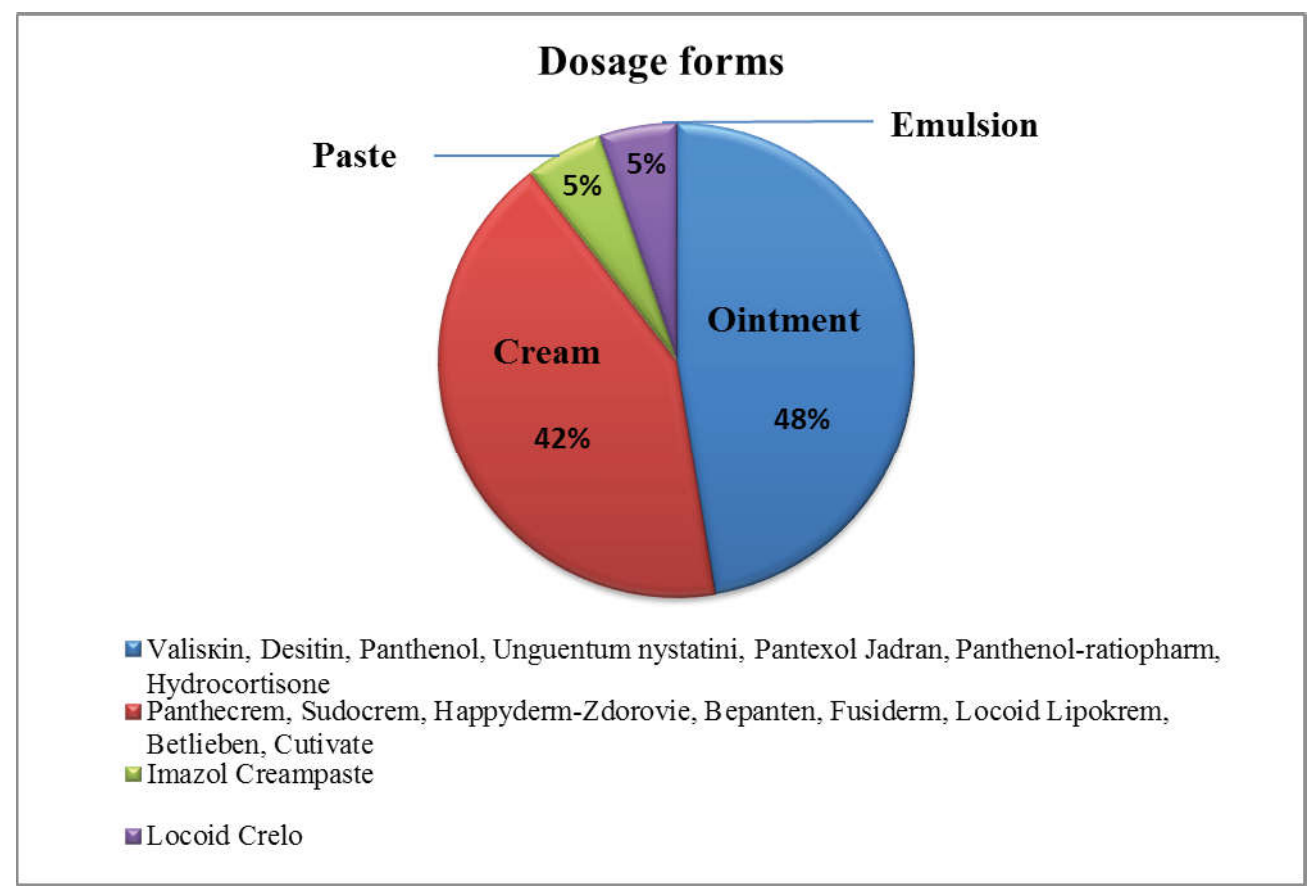

Fig. 1. Dosage forms of drugs for the treatment of DD

ISSN 2312-0967. Pharmaceutical review. 2016. № 4 
Фармацевтичний менеджмент, маркетинг та логістика Pharmaceutical management, marketing and logistics

Table 3. Manufacturers of medicines for the treatment of DD

\begin{tabular}{|l|l|}
\hline \multicolumn{2}{|c|}{ Manufacturer National } \\
\hline \multicolumn{2}{|c|}{ Name of drugs } \\
\hline PJSC “Lubnyfarm", Ukraine & Unguentum nystatini \\
\hline PJSC "Fitofarm", Ukraine & Valiskin, Panthecrem \\
\hline Pharmaceutical company "Zdorovie" Ltd, Ukraine & Happyderm-Zdorovie \\
\hline \multicolumn{2}{|c|}{ Foreign } \\
\hline Spirig Pharma AG, Switzerland & Imazol creampaste \\
\hline KIK Custom Products, Canada & Desitin \\
\hline Forest Tosara Limited, Ireland & Sudocrem \\
\hline "Hemofarm" AD, Serbia & Panthenol \\
\hline "Jadran" Galenski Laboratorij d.d., Croatia & Pantexol jadran, Betlieben \\
\hline GP Grenzach Produktions GmbH, Germany & Bepanten \\
\hline Merkle GmbH, Germany & Panthenol-ratiopharm \\
\hline Фapма Iнтернешенал, Йорданія & Fusiderm \\
\hline Glaxo Operations UK Limited, UK & Bactroban \\
\hline PJSC Nizhpharm, Russian Federation & Hydrocortisone \\
\hline Temmler Italia S.r.l., Italy & Locoid Crelo, Locoid Lipokrem \\
\hline GlaxoSmithKline Pharmaceuticals S.A, Poland & Cutivate \\
\hline
\end{tabular}

children in age 3-6 months. It should also be noted that the nature of the disease is influenced by the individual characteristics of the child, this requires a differentiated approach to the choice of therapy in each case. The creation of an effective pediatric medicines both industrial production and extempore formulation according to the requirements of good manufacturing practice and good pharmacy practice is an actual problem.

\section{Bibliography}

1. Bokova T. A. Pelionochnyi (pampersnyi) dermatit $u$ detei - podhody k profilaktike e lechenyu / T. A. Bokova, G. V. Maslikova // Practica pedatra Sent. - 2016. - S. 42-44. 2. Derzhavny rejestr likarckih zasobiv Ukrany. [Electronniy resurs]. - rezhum dostupu: http://www.drlz.com.ua/ 3. Zakharova I. N. Pravilnyi uhod za kozhey novorozhdennuh e detei rannego vozrasta: chto nuzhno znat pedatru / I. N. Zakharova, E. E. Pshenichnikova-Machneva // Pediatria. - 2016. - No. 1. - P. 24-30.

4. Kompendium. [Electronniy resurs]. - rezhum dostupu: http://compendium.com.ua/

5. Marushko Yu. V. Prophylactichni ta likuvalni zahody pry Pelushkovomu dermatyti u ditei / Yu. V. Marushko // Zdorovie rebenka. - 2015. - №2 (61). - S. 107-111.

6. Moiseenko O. R. Analys zahvoruvanosti ditei pershogo roku zhuttia v Ukranini/ O. R. Moiseenko // Perinatologya e pediatria. - 2010. - №1 (41). - P. 6-9.

7. Unifikovanyi clinichnyi protocol pervinnoi, vtorinnoi (spetsializovanoi), tretinnoi (vysoko specializovano) medichnoi dopomogy. Atopichnyi dermatit// Nakaz Minsterstva ohorony zdorovia Ukraini 04.07.2016 No. 670

8. Diseases and Conditions. Diaper rash. By Mayo Clinic Staff. - May 08, 2015. [Електронний ресурс] - режим доступу: http://www.mayoclinic.org/

9. Neil K. Kaneshiro, David Zieve, the A.D.A.M. Editorial team. Diaper rash/ Medical Encyclopedia. - Oct 7, 2015. [Electronniy resurs]. - rezhum dostupu: https://medlineplus.gov/ 10. Neonatal and Infant Dermatology / [Lawrence F. Eichenfield, Ilona J. Frieden, Andrea Zaenglein, Erin Mathes]. 2014

11. Ravanfar P. Diaper dermatitis: a review and update / P. Ravanfar, J. S. Wallace, N. C. Pace // Curr. Opin. Pediatr. - 2012. - Vol. 24(4). - P. 472-479.

12. Ruchir Agrawal, Dirk M Elston. Diaper Dermatitis. Aug 11, 2016. [Electronniy resurs]. - rezhum dostupu: http://emedicine.medscape.com/

13. World Health Organization. Working document QAS/08.257. Development of paediatric medicines: Points to consider in pharmaceutical development/ Rev.3 August 2011.

ISSN 2312-0967. Фармацевтичний часопис. 2016. № 4 
Фармацевтичний менеджмент, маркетинг та логістика

Pharmaceutical management, marketing and logistics

\section{ОГЛЯД ЛІКАРСЬКИХ ЗАСОБІВ ДЛЯ ЛІКУВАННЯ ПЕЛЮШКОВОГО ДЕРМАТИТУ НА ФАРМАЦЕВТИЧНОМУ РИНКУ УКРАЇНИ}

\section{О. М. Глущенко, Т. А. Буткевич, Р. М. Хоменко}

Національний медичний університет імені О. О. Богомольця, Київ

Резюме: пелюшковий дерматит зустрічається у кожної другої дитини першого року життя. Основними причинами його розвитку вважаються порушення бар'єрної фрункції шкіри та неправильний догляд за нею. У роботі проаналізовані дані літературних джерел щодо причин виникнення, симптоматики, профілактики та лікування пелюшкового дерматиту, досліджений асортимент лікарських засобів на фрармацевтичному ринку України, що використовуються для його лікування.

Ключові слова: пелюшковий дерматит, лікарські засоби, аналіз фрармацевтичного ринку.

\section{ОБЗОР ЛЕКАРСТВЕННЫХ СРЕДСТВ ДЛЯ ЛЕЧЕНИЯ ПЕЛЕНОЧНОГО ДЕРМАТИТА НА ФАРМАЦЕВТИЧЕСКОМ РЫНКЕ УКРАИНЫ}

\section{А. Н. Глущенко, Т. А. Буткевич, Р. М. Хоменко}

Национальный медицинский университет имени А. А. Богомольца, Киев

Резюме: пеленочный дерматит встречается у каждого второго ребенка первого года жизни. Основными причинами развития дерматита считаются нарушения барьерной функции кожи и неправильный уход за ней. В работе проанализированы данные литературных источников причин возникновения, симптоматики, профилактики и лечения пеленочного дерматита, исследован имеющийся на фрармацевтическом рынке ассортимент лекарственных средств, использованных для его лечения.

Ключевые слова: пеленочный дерматит, лекарственные средства, анализ фрармацевтического рынка.

Отримано 09.11.2016

ISSN 2312-0967. Pharmaceutical review. 2016. № 4 